\title{
OROMO PROVERBS AND PROVERBIAL EXPRESSIONS IN THE CUSTOMARY JUDICIAL SYSTEM IN ETHIOPIA
}

\author{
MEGERSA REGASSA TOLASA \\ Lecturer \\ Department of Oromo Folklore and Literature \\ College of Social Sciences and Humanities \\ Jimma University \\ PO Box 378 Jimma, Ethiopia \\ e-mail: megersareg@gmail.com \\ DEJENE GEMECHU CHALA \\ Associate Professor \\ Social Anthropology \\ Jimma University \\ PO Box 378 Jimma, Ethiopia \\ e-mail: dejemmoti_33@yahoo.com
}

\begin{abstract}
This paper discusses the role of Oromo proverbs in conflict resolution and/or management as a peace-making verbal communication principle in the cultural context. The lesson from proverbs, which contain traditional morsels of wisdom, consists of cultural value and rhetorical effectiveness helping to enforce reality in the context in which they are used. Data for this paper is generated from primary sources. In data gathering, we used interview and focus group discussion. The analysis shows that proverbs have persuasive power to advise, guide and influence conflicting parties to settle their case peacefully. The proverbs tell their truths about conflict situations and devise a resolution and management approach through metaphorical and symbolic representations. Proverbs are also an integral part of Oromo culture, handing down and imparting norms, values, rules and the worldview of the community to guide people to live in customary ways.
\end{abstract}

KEYWORDS: conflict • conflict resolution • communication • oral literature • Oromo proverbs

\section{N T RODUCTION}

The questions what is conflict and what causes conflict are important in the study of conflict and conflict resolution. Conflicts exist at different levels and as part of daily 
societal lives. Conflicts possibly lead to violence, hostility and war. However, if conflicts are handled constructively, they are not always destructive; they can also be methods of attaining something leading to change and wisdom (Vestergaard et al. 2011: 3). Likewise, there is a common understanding that conflict is an important part of life that is not necessarily a problem; rather, the problem lies with the inability of the parties to understand how to resolve conflicts as intricate parts of life (Ademowo and Balogun 2014: 39). In a more explicit manner, a Marxist view of conflict would view it as the primary stimulus for social change, which is built into every social system (SeymourSmith 1986). Most scholars also agree that conflict is culture itself (Bohannan 1967; Nanda 1994; Schellenberg 1996).

Ira William Zartman (2000: 1) indicates that before the interference of colonisation, traditional societies in Africa and elsewhere are reputed to have head mechanisms of peace-making locked in their ways, formed from centuries of custom. To solve these conflicts, in African societies traditional institutions and their wisdom are able to efficiently enforce and adjudicate conflicts, infrequently leading to decisions that require recourse to the legal court systems (Joireman 2011: 9).

Traditional African communities have centuries-old experience of customary methods of reconciliation and conflict resolution. The main objectives of these methods are restoring peace by fixing damaged relationships and bringing justice. In this procedure, attempts are made to reintegrate the conflicting parties into their societies and accept a spirit of co-operation. (Brock-Utne 2001) This results in the healing of a broken peace and the reunification of relationships divided by conflict (Kalunta-Crumpton and Agozino 2004: 159). From the traditional way of dealing with conflict, proverbs and proverbial expressions have a vigorous role in managing the interaction of people. A good understanding of proverbs and their implications would help a lot in peaceful coexistence and the appreciation of disagreement as an intricate part of life (Ademowo and Balogun 2014: 39). Different communities have proverbs that have the power to resolve conflict; equally, they have proverbs that depict prejudice relating to the different divisions of society (Gebregeorgis 2015: 227). Similarly, some proverbs mark the rule of conduct for handling conflict situations and are generally prescriptive in nature. In this respect, proverbs provide advice on methods through which conflict can be peacefully settled without partiality. (Adegoju 2009: 67)

The strength of the proverb is that it uses metaphor to clarify people's environment, and therefore the people who use proverbs can easily understand their meaning. If a court passes judgment in a single statement people can easily find justification for its decision through the imagery of proverbs (Mandova and Wasosa 2013: 874). Additionally, since proverbs contain traditional observations that serve to guide people in their day-to-day activities the use of images in conflict resolution discourse is beneficial (Adegoju 2009: 67).

Proverbs hold much significance for nearly all African people (Westermann 1995: 34). They help them as tools to persuade actors during the settlement of disputes; teach communal morals; expound lessons of good and evil; provide guidance on the right actions and explicate the need for and profits of mutual understanding and peaceful coexistence (Gebregeorgis 2015: 228). Proverbs reflect general truths by reference to a specific phenomenon or experience (Okpewho 1992: 227). Additionally, proverbs are meaning-governed expressions the main function of which in conversation is to give 
cultural depth to a speakers' thoughts (Adeeko 1998). Proverbs also enable the avoidance of lengthy accounts during court sessions, helping both to save time and to give an appropriate account of events (Mandova and Wasosa 2013: 872). When they are used or performed in particular contexts, they are meaningful and have great significance (Akoto-Abutiate 2014a: 74). Therefore, proverbs and proverbial expressions are a holistic approach in the context of managing and resolving conflict in Africa (Adegoju 2009).

"Proverbs are sayings that are pregnant with meaning. Proverbs are like shadows. You have to move with them and they move with you." (Akoto-Abutiate 2014b: 37) The proverbs retain their significance because of the built-in option of bettering one's situation (Westermann 1995: 44). The pleasing rhetorical forms, for which proverbs are well known, therefore, constitute the powerful mediation that enables a community to hand down its wisdom across time and distance (Adeeko 1998).

Proverbs have the power to invoke one's thoughts by explicating the issue under discussion (Mandova and Wasosa 2013: 872). They are also storehouses of wisdom to be learned and used by fledging orators (Abrahams 1972: 118). In the African context, proverbs are confirmed to have "wittiness and persuasive effectiveness toward understanding conflict situations and devising strategies for resolving them" (Adegoju 2009: 55). Therefore, proverbs have a number of functions in the court system. Some of these functions include prosecuting, adjudicating on and summarising the proceedings, condemning offenders and teaching societal values. Proverbs are also part and parcel of people's cultural scheme and enable leaders to guide their people in the way they conduct themselves, including conduct within their judicial system. (Mandova and Wasosa 2013: 871) This study focuses on the role of Oromo proverbs in conflict resolution.

\section{RATIONALE OF THE OROMO AND THEIR PROVERBS}

The Oromo are an ancient people, often considered the indigenous people of the Horn of Africa. They are the single largest national group in Africa and speak a language called Afaan Oromo, which is the East Cushitic language of the Afro-Asiatic language group. This language is the third largest Afro-Asiatic language in Africa after Arabic and Hausa. The Oromo constitute the largest population of Ethiopia. (Samatar 1992; Minahan 2002) They have a rich cultural heritage and democratic political system called gadaa. ${ }^{1}$ Their political, economic, social and cultural activities operate under the gadaa system (Legesse 1974; Gow 2002). Proverbial literature is part of the "gadaa historical account and social criticism and; calls for a proper way of human relations and is a crying need for sanity and democratic conduct" (Gemeda 2012: 136). Like other African traditional societies, in their use of proverbs the Oromo mainly stress problems in relation to social and moral issues (ibid.). The Oromo defined proverb in different ways, expressing its importance as "A stew without salt... a speech without a proverb is tasteless"'2 (Gonfa 2008: 40).

Eshete Gemeda (2012: 136) stated that the development of Oromo proverbial literature is linked with the Gadaa system, which has a democratic foundation, the notion of a balanced way of life and a sense of equality. Thus, in the procedure of conflict settlement, the Oromo use proverbs to counter social disruption, moral unsuitability and behavioural incorrectness. Likewise, Sena Gonfa (2008: 53) discussed the role of 
Oromo proverbs at their public meetings and during legal proceedings. She confirmed that proverbs are used to bring up cases, explain them through analogy and to facilitate decision-making using condensed phrases or sentences within a short time.

A number of authors have presented the role of Oromo proverbs. For instance, Gonfa (2008) focuses on different Oromo proverbs and sayings from a gender point of view. Abdullahi Shongolo and Günther Schlee (2007) thoroughly discuss Borana proverbs in their cultural context. Sahlu Kidane (2002) also gave an overview of the role of proverbs in conflict management through his focus on folk tales. Similarly, research on conflict resolution among the Oromo touched upon the role of sayings and proverbs in customary legal proceedings, although in passing only. For instance, Dejene Gemechu (2007; 2011); Fiseha Assefa, Gebre Yntiso and Fekade Azeze (2011), and Megersa Regassa and Gemechu (2015a; 2015b) indicate that proverbs and sayings are commonly used in the processes of conflict resolution. They are used alike by mediators, facilitators and contenders to confess, to persuade people to tell the truth, to submit to negotiation, respect mediators, and act within given norms. However, in none of these works are proverbs taken as the central point of discussion. In spite of the importance of these works, "the study of Oromo proverbial folklore shows that in almost all cases scholars provide surface level explanations, translation into English and other European languages", as Gemeda (2012: 136) indicates. The following long quotation, following on from this, indicates the gap in the study of Oromo proverbs and suggests that the gap be filled by folklorists. Gemeda (ibid.: 137) says:

Moreover, nothing significant is mentioned about their aesthetic background and the situations in which the aphoristic sayings are performed. All the events of proverbial texts have cultural implications and are strongly influenced by the present social circumstances. Thus, it is of paramount importance to assess the extent of these influences, the way they can be recognised as social products and whether or not the cultural interpretation of the text takes into consideration such influences. It is, therefore, the folklorists' duty to probe into how the core idea of literary tradition is related to its social setting. This means, in discussing a whole corpus of wisdom literature, we need to focus on its social use and the way the entire body of tradition is congruent with the structure of a given society in which the literary genres are produced.

Therefore, the present study aims to fill this gap in Oromo proverbs in general and their role in conflict resolution in particular. It focuses on proverbs that are directly and/or indirectly related to conflict resolution and takes as its central objective a depiction of the functional role of proverbs in the processes of conflict resolution among the Oromo.

\section{METHODS}

A qualitative approach was used for this research paper. Primary data were collected from the field employing interview, observation, and focus group discussion methods. Through interview, different proverbs that are related to conflict management and resolution were collected from 15 selected elders of both sexes. The selected elders are those who have rich experience in using proverbs in their daily discourse and in resolv- 
ing conflict. These informants were able to jot down several proverbs which can be used in the processes of handling conflict. More importantly, elders were able to clarify the metaphoric meaning of proverbs in relation to their theme.

The second method used to collect data for this study was observation. The stages of customary conflict resolutions where observed at Omo Nadda of Jimma Zone, and Limmu and Haro Limmu districts of East Wollega, Oromia, Ethiopia. Proverbs used by mediators and disputants on the stages of conflict resolution where collected.

The third is focus group discussion. Discussants were selected based on their experiences and participation in conflict resolution as arbitrator, mediator and/or negotiator. Three FGDs were formed consisting of eight individuals each. This method was important not only in collecting several proverbs, but also in securing some of their meanings in social communication with regard to conflict resolution and harmonious relationship building. In addition to field notes data were captured by audio recorder and digital camera.

Through the above stated methods of data collection, more than 300 proverbs that contribute in conflict management and resolution were secured from the community. From the collected proverbs only 50 were selected and analysed for this study. This is mainly because it was too much to analyse all 300 proverbs in a single article. In the meantime only some proverbs are directly and unconditionally related to the theme of conflict management and resolution. A qualitative data analysis approach is used in which the selected proverbs were subjected to content analysis. In the content analysis emphasis was placed on the use of proverbs in the culturally determined context of conflict resolution and its meaning as well as its contribution to maintenance of a peaceful social life.

The data were collected in the field in Afaan Oromo and translated into English after the fieldwork was completed. After translation the data were transcribed, assembled, ordered, and structured according to their similarity and themes in relation to conflict management, conflict resolution and peace-making principles. They were then classified under rubrics relating to their role in conflict resolution and management.

\section{LITERATURE REVIEW: CONCEPTUAL AND \\ THEORETICAL FRAMEWORK}

As far back as Aristotle scholars from many disciplines have attempted to define what a proverb is. Archer Taylor (1931) affirms that definition of proverb is too difficult. However, many scholars tried their best to define proverb. Wolfgang Mieder (2014: 1) stated that proverbs "fulfill the human need to summarise experiences and observations into nuggets of wisdom that provide ready-made comments on personal relationships and social affairs". To show that proverb is pervasive, the author added that "there are proverbs for every imaginable context, and they are thus as contradictory as life itself". In Dorothy Bea Akoto-Abutiate's (2014b: 37) work, proverb is defined as a saying that is pregnant with meaning. The context in which a proverb is used determines its meaning.

Isidore Okpewho (1992: 226) defines proverb "as a piece of folk wisdom expressed with terseness and charm." The terseness implies a certain compression in the selection of words and a sharpness of focus, while the charm displays the touch of literary or 
poetic beauty in the expression. Likewise, Adeleke Adeeko (1998) explains that proverbs are short, witty and widely known to members of the speech community and enable speakers to communicate efficiently. Additionally, Neal Norrick (1985: 36) defines proverbs as autonomous, "pithy, traditional expressions with didactic content and fixed, poetic form". As Roger Abrahams (1972: 119) says, proverbs are short and witty traditional expressions that arise as part of daily communication as well as in the more highly structured circumstances of education and judicial proceeding. Chinua Achebe (1996: 5) describes proverb as "palm-oil with which words are eaten" as a way of pointing out that proverbs are a short form of speech that talk about broad issues in few words. Mieder (1985: 119) says: "A proverb is a short, generally known sentence of the folk which contains wisdom, truth, morals, and traditional views in a metaphorical, fixed and memorizable form and which is handed down from generation to generation."

A socio-semiotic approach is the theoretical framework used for this study of proverbs. According to Jan Renkema (2004: 46), the central point of this approach is the study of every discourse in its social context, in the culture and situation in which it appears. Likewise, Michael Halliday and Ruqaiya Hasan (1985) identified three concepts used to interpret the social context. These are field, tenor and mode. As the authors argued, these concepts are useful to interpret the social context of a text, i.e. the situation in which meanings are being exchanged (ibid.: 12). Halliday and Hasan (ibid.) further explain the three concepts as follows: the field of discourse is what is going on and the nature of social action that is being experienced. More specifically, it focuses on the enquiries into what the participants are performing, in which language shows as an important factor. In this study, we have discussed the social action in which participants engaged, i.e. conflict resolution discourse. The metaphorical meanings of Oromo proverbs in the context of conflict management and resolution are stated. Halliday and Hasan (ibid.: 12) added that the tenor of discourse refers to who is taking part, to the nature of participants, to their status and roles. It says something about the kinds of role relationship that exist between the participants. It explicates both the types of speech role that participants assume in dialogue and the whole cluster of socially significant relationships in which they are involved. In relation to this, in the present study, we have discussed the elders who participate in conflict resolution and the affect that knowledge of proverbs has on selecting elders for conflict resolution.

Additionally, Halliday and Hasan (ibid.) discussed how the "mode of discourse refers to what part the language plays and participants' expectations about what language can do for them in that situation". Therefore the symbolic organisation of the text, its status, and its function in the context, including the channel (spoken, written or a combination of the two) and the rhetorical mode. Finally, this quote says something about what the text achieves in terms of persuasive, expository, and didactic categories and the like. For this study, the mode of discourse has helped us to discuss the role of Oromo proverbs and proverbial expressions in context of conflict management and resolution. We have discussed the goal proverbs realise in terms of their persuasive, expository and moralistic influence. Additionally, the role of proverbs in persuading conflicting parties to agree by showing them reality through a rhetorical and imagery description of the theme and the case under discussion has been explained. 
This part presents Oromo proverbs that are commonly used to urge conflicting parties to resolve their differences. Indeed, there is no single proverb that is exclusively used to resolve conflict. Rather, proverbs are used in different contexts of social communication. The Oromo express the pervasiveness of proverbs through proverbs themselves. When they say "To spit saliva one should say ' $a a k$ ', to present an issue one should use a proverb", ${ }^{3}$ this implies that a proverb is one way of communicating an idea of any kind.

Another Oromo proverb says "Proverbs open a discussion as well as closing it". 4 The Oromo proverb "As a calf resembles the bull, a proverb resembles the issue under discussion" ${ }^{\prime \prime}$ indicates that proverbs are context dependant. In spite of the vital role and multiple functions of proverbs in Oromo communication, the current study focuses on proverbs that are frequently used for the purpose of conflict resolution and/or management. In the analysis and discussion, proverbs are categorised according to the themes they convey that are relevant to conflict management and/or resolution. Additionally, the persuasive power and metaphoric meaning of proverbs also analysed in relation to conflict and conflict resolution strategies.

\section{Proverbs on the Inevitability of Conflict}

The Oromo express how conflict is inevitable, exists everywhere and is impossible to end. This is stated by the Oromo proverb, "Even hearthstones collide with each other". 6 The proverb tells us that, just as it is difficult to protect hearthstones from colliding, so it is impossible to prevent conflict. Oromo traditional hearthstone consists of three stones placed in a triangular form. One is unmovable and the remaining two are mobile to fit different cooking or baking equipment. When they moved here and there, the two movable hearthstones often collide. The proverb tells of the inevitability of conflict by comparing the common collision of hearthstones with conflict, suggesting it is part of human life. Even if the hearthstones collide, they continue serving together. If one of the stones is missing, the remaining two cannot serve their purpose.

The proverb "An abhorrent thing is vomit, but it comes persistently" same implication. In the context of conflict resolution and/or management, mediators metaphorically compare vomit with conflict. The implication is that as no one wants to vomit, just as no one likes conflict, but both are inevitable, they happen unexpectedly.

Through proverbs, the Oromo indicate that conflict results in changes to society, some of which can bring positive ends. The Oromo proverb "To be cleaned, things should first be polluted" ${ }^{\prime 8}$ refers to how conflict leads to change. This proverb implies that in the same way polluted water can be cleaned, things are cleared and settled after conflict implying that conflict can clean inequality, bias, prejudice and bring change to a community.

Similarly, the Oromo express through proverbs how a person or people living next to a belligerent person or people encounter everlasting conflict. The proverb, which reads "Cactus tree neighbours to the thorny plant cry every time" ${ }^{\prime}{ }^{9}$ is used to show this. The proverb implies that when the wind blows it makes the thorny plant and the cactus tree collide with one another, so that the thorn penetrates the cactus. As a result, latex 
comes from the cactus tree symbolising tears. In this proverb, the thorny tree symbolises a belligerent person or people and the cactus tree symbolises a peaceful people who are antagonised by them. In addition, the latex symbolises the suffering they experience at the hands of the aggressive people.

\section{Proverbs on the Causes of Conflict}

There are proverbs that show the immediate causes of conflicts. Most of the time, conflict is caused by the unexpected. The Oromo proverb shows it as "A child who is about to cry, the calf stood on his/her leg". ${ }^{10}$ This proverb implies that conflict is often caused by instant reactions rather than gradual and deep-rooted problems. This proverb is used by elders to soften the issue of conflict and encourage conflicting parties to relax and prepare for settlement of the case. To resolve a conflict the cause of which is simple, elders also use proverbs to discredit the conflict itself or to indicate that it is not deeply rooted. The proverb used in this context is "Children and dogs cause conflict between neighbours" .11 This proverb says that the cause of the conflict under discussion is children and/or dogs, i.e. children from different households play together and possibly quarrel, conflict that can easily extend to the parents but can be easily resolved through the goodwill of all parties because the root causes are negligible.

\section{Proverbs to Promote Respect and Criticise Disrespect}

In Oromo, many proverbs are used to promote respect and criticise attitudes and acts of disrespect. For this, the following proverb is a fitting example: "What the tongue breeds or generates, the bull could not". ${ }^{12}$ The proverb indicates that a sharp tongue has the power to generate bad or humiliating words that possibly cause conflict or punishment from God. For instance, if someone insults someone else because he/she is blind, the attacker may become blind. This is what his/her tongue brought on. Therefore, elders advise the conflicting parties not to offend each other by speaking disparagingly.

The other proverb used to teach respect is, "Communicating through the good word is better than providing a good bedroom". ${ }^{13}$ This proverb compares the "good word" and the 'good bed'. The good word implies politeness and the good bed implies material service that someone provides to somebody else. The proverb shows that showing politeness to others is better than giving them material benefits. The proverb provides a lesson in polite communication and respect. The proverb "A tongue has no bone, but breaks human bone"14 is also used to indicate the importance of polite communication and to criticise attitudes of disrespect. This proverb also implies that the insult that comes from the tongue can harm others psychologically. The 'human bone' in this proverb allegorically implies psychological wellbeing, which can be harmed by words. Therefore, the lesson of this proverb is that discouraging others through insults, etc., is not a good way of communicating.

Furthermore, Oromo proverbs also used to discourage using bad words when speaking to others. Bad words or insults harms not only the person who is insulted, but also the speaker him/herself. The following proverb attests to this fact: "Coming out of 
one's mouth, a bad word harms the speaker".${ }^{15}$ This proverb implies that the person who used unnecessary and disagreeable discourse may experience suffering because of what he/she said. Therefore, this proverb instructs one not utter bad word against others. The next proverb also asserts the harm that bad words cause to social relationships. "Time will pass; take care not to speak bad words, which never pass"16 implies that even though a conflict is settled, or the cause of it settled, and the conflict long forgotten, bad words spoken during the conflict remain unforgotten. The proverb teaches the lesson that a bad word is more abhorrent than any other form of dispute. Because this kind of language can escalate a conflict mediators use this proverb to advise conflicting parties not to speak bad words to each other.

These proverbs commonly used in day-to-day communication as well as in advising conflicting parties to take care of their words when making claim and counter claim. Regardless of the situation in which the speakers find themselves, it is advisable to be polite and respect others.

\section{Lessons in Truthfulness and Honesty from Proverbs}

In Oromo, truth is the most important element of social relations. In contrast, a lie or deceit has no place in their social, economic, political, religious and cultural lives. There are different proverbs supporting this view, "Truth is the son of God"17 being one of these. This proverb states that truth belongs to God not only to human beings. This implies that any one not speaking the truth is speaking against God. If the truth is broken or hidden, God will intervene to find and correct it, punishing the person who hid or misrepresented it. Similarly, the proverb "The path you walked while lying will cause you to suffer when you return"18 shows how the lie will be exposed somewhere, perhaps somewhere other than its original context. When the lie is exposed the liar will suffer the consequences.

The proverb "Even if it became thin, the truth would not fail"19 is in the same category. This proverb says that ultimately the truth is something that cannot be hidden. The person who is truthful will win, even if he/she currently suffers. That is because God intervenes to help the person with the truth for He is always in favour of the truth. There is another proverb that shows God's interference on the side of truth, saying "Even if you start the journey early in morning, you cannot escape from God". ${ }^{20}$ This proverb is used by elders in conflict resolution when advising disputants who refuse to speak the truth. The lesson from this proverb is that by hiding the truth one cannot hide oneself from God no matter how hard one tries. Another proverb emphasising the truth is, "Even though an eye can disappear, its place does not". ${ }^{21}$ People use this proverb to imply that the truth is something that cannot be ignored or hidden completely.

\section{Proverbs for Tolerance, Unity and Patience}

Oromo cultural values are based on collectivism rather than individualism. There are Oromo proverbs displaying social unity and cooperation in triumph as well as in misery, trouble and disparity. The proverb "A stranger on the day of celebration, a relative 
on the day of suffering" 22 is relevant to this point. This proverb compares two categories: strangers and relatives implying that anyone will be friendly when there are no difficulties, but when problems arrive you can only rely on your relatives. This proverb is used to advise conflicting parties to unite and seek help and to stand with one another in hardship. The other proverb to show the importance of family is "Even though he/ she behaves poorly, one's relative is one's own companion". ${ }^{23}$ This proverb shows that no one should push away a relative in times of difficulty, suggesting that family differences should be put aside when settling any case of conflict with one's relatives.

Proverbs also advise about tolerance. For instance, if there is conflict between brothers and sisters who are economically dependent on their parents, the following Oromo proverb can advise the disputants: "When the ficussur tree does not complain, birds fight each other over the ficussur fruit" ${ }^{24}$ The ficussur tree has abundant fruit, enough for the birds, yet they still fight each other. This proverb encourages conflicting parties, or society at large, to take a lesson from birds and equally share their communal natural resources given by God to share. The proverb "People who build one house do not clash over grass covering the same house ${ }^{\prime 25}$ also talks about the need for tolerance and cooperation among people who share the same goal. Because the grass is being used to construct a house that everyone will live in, a dispute over the grass would be pointless. This shows that in order to achieve success when striving for a common goal, unity and understanding are indispensable.

The proverb "Through unity, fibres can tie an elephant" ${ }^{26}$ counsels the importance of social unity by emphasising the outlook of collectivism. A single fibre or thread is very weak and can easily be broken. However, when many threads are added together, they become a strong rope that can tie even an elephant, implying that unity is strength. The other Oromo proverb "Ants cross the river by cooperation" 27 also advises unity and cooperation, stressing that unity is strength. This proverb implies that the same is true for human beings. Using this proverb, elders give advice to conflicting parties that they should unite to their advantage.

Another Oromo proverb used to advise submission to the demand of the majority is, "It is better if a mountain falls onto an individual than society fall onto him/her". ${ }^{28}$ In this proverb, society falling onto the individual is a reference to being under social sanction or being prohibited from receiving help from the community. No one is able to survive under such conditions because life is communal and interdependent. The proverb implies that no one can live without social cooperation. The next proverb to depict the importance of social unity is, "In the morning, when a person leaves the house first he/she meets his/her neighbours, and the sun" ${ }^{29}$ This proverb shows the importance of good relationships between neighbours. When someone encounters a problem, the first people to arrive are the neighbours. A similar proverb also shows the importance of peaceful neighbourly relations: "To have a neighbour is to have a cloth", 30 implying that, in the same way that cloth covers the human body, neighbours also supports one in tackling problems.

There are Oromo proverbs that emphasise lessons of tolerance among close relatives and friends. One example is, "Even if one's finger is wounded, one cannot cut it off". ${ }^{31}$ The elders use this proverb to advise conflicting parties to show compassion to each other. The meaning is that if someone's finger is wounded, he/she should not cut it off but rather heal it. The wounded finger symbolises the person who is misbehaving, and 
the proverb is used to advise one of the conflicting parties to show compassion for the wrongdoer rather than pursuing vengeance.

\section{Proverbs for Pardon or Forgiveness}

Oromo proverbs prioritise the importance of ignoring conflict and its causes. For example: "Probing the cause of conflict intensifies the problem, ignoring it ends the case". ${ }^{32}$ Through this proverb the elders advise conflicting parties to open their hearts to compassion.

The next proverb is also used to counsel conflicting parties to disregard conflict and strive for reconciliation. "Leaving aside the conflict and giving mercy enables someone to live on his own father's land"33 says that, in conflict resolution the conflicting parties should sidestep the conflict and its causes and rather work on settling the case. Unless the problem is resolved at that point, the conflict could intensify and cause physical harm which would be even more hurtful as the harmful result of the conflict might cause the conflicting parties to leave their land to escape revenge.

The next proverb also shows the importance of ignoring root causes of conflict in order to bring calm: "As one cannot kiss one's own back, one cannot address all things in conflict resolution procedures". ${ }^{34}$ Elders use this proverb to advise conflicting parties not to speak too much about the conflict and its causes, which might possibly inflame the conflict. This is similar to the proverb, "A hen repeatedly digs the ground and exposes a knife that cuts her own throat". ${ }^{35}$ Metaphorically this proverb hints at the fact that if the conflicting parties speak too much about the conflict at the expense of its settlement, the case becomes more complex and resolution becomes more difficult, thus harming the speakers. This proverb is used by mediators to urge conflicting parties to come to an agreement quickly.

\section{Proverbs on Agreement, Peace and Dispute Settlement}

Oromo proverbs stress the importance of resolving conflict. The proverbs are used during conflict resolution discourse to advise conflicting parties to settle their case peacefully. The most important proverb for this issue is, "When people are having a conflict on the ground, they cannot climb a tree together". ${ }^{36}$ This proverb implies that people who disagree might throw one another down if they climbed a tree together. The proverb gives a lesson that in order for people to perform difficult tasks together must first agree. People, who disagree on small things, cannot achieve extraordinary things. The other proverb used to show the importance of agreement between conflicting parties is, "It is only possible to enter a house after an agreement" ${ }^{37}$ This proverb shows that disagreements push people away from each other and hamper peaceful coexistence, while agreement makes them live cooperatively, the same being true of society in general. The Oromo also say, "People advancing toward disasters curse each other; those succeeding to development bless each other" ${ }^{38}$ The proverb is used to show the position of peace for conflicting parties as well as the overall community. It implies that development is a 
result of peaceful coexistence exemplified through love, respect and agreement.

The Oromo believe that conflict can be resolved through peaceful discussion. The proverb expressing this is, "People who sit down together to find a solution will not miss the solution". ${ }^{39}$ The proverb implies that all types of conflict can be resolved by reconciliation discussions between mediators and disputants. The next proverb also shows the disadvantage of refusing the decision of mediators: "Who refuses advice will not refuse death". ${ }^{40}$ The proverb implies that a person who refuses to accept the decision of elders or mediators will experience trouble as a result that might even lead to death.

Mediators use proverbs to show conflicting parties that agreement with a judgment is beneficial. They say, "If one refuses the word of the elders (mediators) in the morning, one will agree to it in the evening". ${ }^{41}$ This implies that if one of the conflicting parties refuses the mediators' judgment initially, he/she will later regret it and lose much time, only to agree it later since the only solution is to resolve the conflict before the elders. The next proverb also specifies the role of mediators in conflict resolution. The Oromo say, "As legs make a long journey short, elders bring a long dispute to an end". ${ }^{42}$ This again shows how only mediators can settle long and complex cases quickly. In this proverb 'leg' and 'long journey' are metaphorically the elders and the dispute respectively, implying that in the same way that someone can make a long journey on foot, so a deep rooted conflict or dispute also comes to an end when elders or negotiators are used.

When conflict happen, mediators intervene to resolve it immediately before it escalates to more violence. The proverb that says this is, "Liver after one day will be hard as a bone". ${ }^{43}$ This proverb says that when an animal is slaughtered, its liver should be eaten quickly before it becomes hard and difficult to eat. That is, when a conflict is protracted it becomes harder to resolve and therefore it is better to resolve it immediately. Mediators use this proverb to persuade disputants that they should settle their conflict before it gets out of hand. The other proverb expressing the same sentiment is, "Skin should be wrapped when it is wet". ${ }^{44}$ This tells of how a skin needs to be wrapped immediately after an animal is slaughtered otherwise it loses its wetness and cannot be wrapped. Using this proverb, mediators provide instructions to disputants to sit down and be part of a discussion to resolve the conflict as soon as possible.

The next proverb is also used to reinforce the view that it is important to resolve conflict before it escalates: "A short discussion is better". ${ }^{45}$ The other proverb used by mediators to finish conflict resolution discourse is "Even though many words are spoken, they cannot be loaded onto a donkey". ${ }^{46}$ The proverb used is to end or summarise a discussion, dialogue or debate and encourage closure.

The Oromo people give a high priority to peace, viewing it as more important than any material benefit. This is stated in the Oromo proverb "Arriving home in peace is greater than profit of trade". ${ }^{47}$ This implies that for a trader coming back to his/her home in peace from a long journey is a greater benefit than the profit he/she acquired from the journey. This proverb is also used metaphorically as a lesson to conflicting parties that settling conflict and rebuilding peace is more important than the profit they could make from the perpetuation of the conflict. The next proverb also shows the importance of reconciliation. The proverb "Elders (mediators) lie to mediate the parties" ${ }^{\prime \prime}$ shows that elders give priority to the settlement of the conflict by calming down the parties as much as possible. They calm down the irritation caused by conflict and work to rebuild peace. Another Oromo proverb speaks to the importance of an agree- 
ment before adverse action is taken. It says, "The fart released by agreement does not have a bad smell" ${ }^{49}$ This implies that working something out by agreement does not cause conflict, even if its results might not completely please everybody.

Giving this a socio-centric point of view, among the Oromo, conflict not only relates to the conflicting parties, it can affect neighbouring people too. The Oromo say, "One has a peaceful night when one's neighbour remains peaceful". ${ }^{50}$ Therefore, this proverb is used to urge conflicting parties to settle the case for the sake of not only themselves, but also of their neighbours and the general community in which they live. The proverb also encourages people to care for their neighbours, thereby fostering peace.

\section{CONCLUSION}

Among traditional African societies in general and the Oromo in particular, proverbs play a vital role in conflict resolution and conflict management both during the conflict resolution process and in the circumstances of normal social communication. In this context, proverbs are used to show the drawback of conflict and bring about peaceful coexistence within the community. Proverbs are used in many social communications, particularly in the context of conflict resolution and management; they portray conflict, its causes and consequences, promote the habits of respect, truthfulness, honesty, tolerance, unity, patience, and peaceful co-existence among human kind. Therefore, this paper concludes that Oromo proverbs play a pivotal role in conflict resolution and conflict management strategies that work toward reconciliation and restoration of communal peace and harmony.

\section{NOTES}

1 Gadaa is a system that guides the social, cultural, political, religious, economic and military activities of the Oromo people (Legesse 1974).

2 Ittoon soogidda hinqabneefi dubbiin makmaaksa hinqabne hinmi'aawu.

3 Aak jedhan waa tufan, mammaakan waa himan.

4 Mammaksi dubbii fidas; dubbii fixas.

5 Jabbiin korma fakkaatti, mammaaksi dubbii fakkaatti.

6 Gomjiinuu walitti bu'a.

7 Kan jibban diiddiga, namatti siissiqa.

8 Boora'u malee hincaraa'u.

9 Adaamiin olla agamsaa ganamnis boo'icha, galgallis boo'icha.

10 Mucaa boo'a kajeeltu jabbiin irra ejjette.

11 Ijoolleefi sareetu olla waliin ga'a.

12 Kan arrabni dhalchu, kormi hindhalchu.

13 Afaan gaariin hafaa gaarii caala.

14 Arrabni lafee hinqabdu lafee namaa cabsiti.

15 Afaanii bahee gooftaa namaa ta'a.

16 Bara darbuuf jettee jecha hindarbine hin dubbatiin.

17 Dhugaan ilmoo Waaqaati.

18 Karaan sobaan darban deebiitti nama dhiba.

19 Dhugaan qallattullee hincittu. 
20 Ganamaan bahaniif waaqa jalaa hinbahani.

21 Iji baddus bakki ijaa hin baddu.

22 Alagaa gaafa kolfaa, fira gaafa golfaa.

23 Hamaan ofii hamaamota.

24 Osoo harbuun hin dadhabiin simbirri harbuurraa waldadhabdi.

25 Namni mana tokko ijaaru citaa wal hinsaamu.

26 Qunceen wal gargaartee arba hiiti.

27 Goondaan walqabattee laga ceeti.

28 Namni namatti jiguu irra gaarri namatti jiguu wayya.

29 Ollaafi biiftuutti gadi ba'u.

30 Ollaan ofii kafana ofitit.

31 Ajaa'e jedhanii quba ofii kutanii hingatani.

32 Maal jedheen dubbii fidee haa jedhuun dubbii fixe.

33 Haa hafuun biyya abbaa ofiitti nama hambisa.

34 Dugda hindhungatan; hunda hindubbatan.

35 Indaaqqoon haatee haatee waan morma ishee kutu baste.

36 Utuu lafatti waliif hingaliin, muka waliin hin yaabani.

37 Walii galan alaa galan.

38 Baduuf ka'ee wal abaaree marguuf ka'ee wal arraabe.

39 Kan maal goonu jedhe, waan godhu hin dhabu.

40 Hima diddeen du'a hin diddu.

41 Dubbii jaarsaa ganama didanii galgala itti deebi'u.

42 Karaa dheeraa miilatuu gabaabsa; dubbii dheeraa jaarsatuu gabaabsa.

43 Tiruun bulte lafee taati.

44 Gogaa jiidhaatti maru.

45 Dubbiin gabaabaa wayya.

46 Dubbiin baayyatteef harreetti hin fe'amtu.

47 Nagaan galuun nagada caala.

48 Jaarsi sobee nama araarsa.

49 Dhuufuun wal mari'atanii dhuufan hin ajaa'u.

50 Nagaan bulleen yoo ollaan nagaa bule.

\section{REFERENCES}

Abrahams, Roger D. 1972. Proverbs and Proverbial Expressions. - Folklore and Folklife: An Introduction, edited by Richard M. Dorson. Chicago, IL; London: The University of Chicago Press, $117-127$.

Achebe, Chinua. 1996. Things Fall Apart. Oxford: Heinemann Educational Publishers.

Adegoju, Adeyemi. 2009. Rhetoric in Conflict-Related Yoruba Proverbs: Guide to Constructive Conflict Resolution in Africa. - African Study Monographs 30 (2): 55-69.

Adeeko, Adeleke. 1998. Proverbs, Textuality and Nativism in African Literature. Gainesville, FL: University Press of Florida.

Ademowo, Adeyemi Johnson and Noah Balogun. 2014. Proverbs and Conflict Management in Africa: A Study of Selected Yoruba Proverbs and Proverbial Expressions. - International Journal of Literature, Language and Linguistics 1 (1): 39-44.

Akoto-Abutiate, Dorothy Bea. 2014a. African Theology/ies: A Contemporary Mosaical Approach. Bloomington, IN: AuthorHouse. 
Akoto-Abutiate, Dorothy Bea. 2014b. Proverbs and the African Tree of Life: Grafting Biblical Proverbs on to Ghanaian Eve Folk Proverbs. Studies in Systematic Theology 16. Atlanta, GA: Brill. DOI: https://doi.org/10.1163/9789004274471.

Bohannan, Paul. 1967. Introduction. - Law \& Warfare: Studies in the Anthropology of Conflict. Austin, TX: University of Texas Press, xv-xiv.

Brock-Utne, Birgit. 2001. Indigenous Conflict Resolution in Africa. A draft presented at the seminar on indigenous solutions to conflicts held at the University of Oslo, Institute for Educational Research, February 23-24, 2001.

Fiseha, Assefa; Gebre Yntiso and Fekade Azeze. 2011. The State of Knowledge on Customary Dispute Resolution in Ethiopia. - Customary Dispute Resolution Mechanisms in Ethiopia, edited by Gebre Yntiso, Fekade Azeze and Assefa Fiseha. Addis Ababa: Ethiopian Arbitration and Conciliation Centre, 21-36.

Gebregeorgis, Mehari Yimulaw. 2015. Discursive Depiction of Customary Conflict Management Principles in Selected African Proverbs. - Folklore. Electronic Journal of Folklore 62: 225-246. DOI: https://doi.org/10.7592/FEJF2015.62.gebregeorgis.

Gemechu, Dejene. 2007. Conflict and Conflict Resolution among Waliso Oromo of Eastern Macha: The Case of Guma. Social Anthropology Dissertation Series 15. Addis Ababa: Addis Ababa University Press.

Gemechu, Dejene. 2011. The Customary Courts of the Waliso Oromo. - Customary Dispute Resolution Mechanisms in Ethiopia, edited by Gebre Yntiso, Fekade Azeze and Assefa Fiseha. Addis Ababa: Ethiopian Arbitration and Conciliation Centre, 251-277.

Gemeda, Eshete. 2012. African Egalitarian Values and Indigenous Genres: A Comparative Approach to the Functional and Contextual Studies of Oromo National Literature in a Contemporary Perspective. Berlin, Zürich: LIT Verlag Muster.

Gonfa, Sena. 2008. The Images of Women in the Proverbs and Sayings of the Oromo: The Case of West Arsi Area. A Master Dissertation. Addis Ababa University, Department of Foreign Languages and Literature.

Gow, Greg. 2002. The Oromo in Exile: From the Horn of Africa to the Suburbs of Australia. Melbourne: Melbourne University Press.

Halliday, Michael Alexander Kirkwood and Ruqaiya Hasan. 1985. Language, Context and Text: Aspects of Language in a Social-Semiotic Perspective. Victoria: Deakin University Press.

Joireman, Sandra F. 2011. Where There is No Government: Enforcing Property Rights in Common Law Africa. New York, NY: Oxford University Press.

Kalunta-Crumpton, Anita and Biko Agozino. 2004. Pan-African Issues in Crime and Justice. Aldershot: Ashgate Publishing Ltd.

Kidane, Sahlu. 2002. Borana Folktales: A Contextual Study. London: Haan Publishing.

Legesse, Asmarom. 1974. Gada: The Three Approaches to the Study of African Society. New York, NY: The Free Press.

Mandova, Evans and Wellington Wasosa. 2013. The Role of Proverbs in the Shona Judicial System with Special Reference to Nhango Dzokusuma Nyaya Padare. - International Journal of Asian Social Science 3 (4): 871-877. http://www.aessweb.com/pdf-files/ijass-3(4)-871-877.pdf (accessed September 24, 2019).

Mieder, Wolfgang. 1985. Popular Views of the Proverb. - Proverbium: Yearbook of International Proverb Scholarship 2: 109-143.

Mieder, Wolfgang. 2014. Behold the Proverbs of a People: Proverbial Wisdom in Culture, Literature, and Politics. Jackson, MS: University Press of Mississippi.

Regassa, Megersa and Dejene Gemechu. 2015a. Indigenous Mechanism of Conflict Resolution among the Oromo: The Case of Reejjii Institution of Jimma, Ethiopia. - The Journal of Oromo Studies 22 (1): 69-89. 
Regassa, Megersa and Dejene Gemechu. 2015b. Jigaa Institution: The Surviving Gadaa Court among the Jimma Oromo, Ethiopia. - Ethiopian Journal of Social Sciences and language Studies $2(2): 3-23$.

Minahan, James. 2002. Encyclopedia of the Stateless Nations: Ethnic and National Groups Around the World III, $L-R$. Westport, CT; London: Greenwood Press.

Nanda, Serena. 1994. Cultural Anthropology. 5th edn. Belmont, CA: Wadsworth Publishing Company.

Norrick, Neal R. 1985. How Proverbs Mean: Semantic Studies in English Proverbs. Trends in Linguistics: Studies in English Proverbs 27. Berlin: Walter de Gruyter. DOI: https://doi. org/10.1515/9783110881974.

Okpewho, Isidore. 1992. African Oral Literature: Backgrounds, Character and Continuity. Bloomington, IN: Indiana University Press.

Renkema, Jan. 2004. Introduction to Discourse Studies. Amsterdam, New York, NY: John Benjamins Publishing Company.

Samatar, Said S. 1992. In the Shadow of Conquest: Islam in Colonial Northeast Africa. Trenton, NJ: The Red Sea Press.

Schellenberg, James A. 1996. Conflict Resolution: Theory, Research, and Practice. Albany, NY: State University of New York Press.

Seymour-Smith, Charlotte. 1986. Macmillan Dictionary of Anthropology. London: Macmillan Press Ltd. DOI: https://doi.org/10.1007/978-1-349-08037-3.

Shongolo, Abdullahi and Günther Schlee. 2007. Borana Proverbs in Their Cultural Context. Verbal Art and Documentary Literature in African Languages 24. Köln: Rüdiger Köppe Verlag.

Taylor, Archer. 1931. The Proverb. Cambridge, MA: Harvard University Press.

Vestergaard, Bjarne; Erik Helvard and Aase Rieck Sørensen. 2011. Conflict Resolution - Working with Conflicts. Frederiksberg: The Danish Centre for Conflict Resolution. https://konfliktloesning.dk/wp-content/uploads/2017/04/ConflictResolution.pdf (accessed September 24, 2019).

Westermann, Claus. 1995. Roots of Wisdom: The Oldest Proverbs of Israel and Other Peoples. Louisville, KY: Westminster John Knox Press.

Zartman, Ira William, ed. 2000. Traditional Cures for Modern Conflicts: African Conflict 'Medicine'. Boulder, CO: Lynne Rienner Publishers. 